DOI 10.37882/2223-2974.2020.09.04

\title{
ЗАЩИТА ТРУДОВЫХ ПРАВ РАБОТНИКОВ ГОСУДАРСТВЕННОЙ ИНСПЕКЦИЕЙ ТРУДА
}

\section{PROTECTION OF LABOR RIGHTS OF EMPLOYEES OF THE STATE LABOUR INSPECTORATE}

\section{E. Bozukova}

Summary: By virtue of article 21 of the Labor code of the Russian Federation, one of the basic rights of employees is to protect their labor rights, freedoms and legitimate interests in all ways not prohibited by law. In our article, we will talk about one of the ways to protect violated labor rights of employees - the state control (supervision) over compliance with labor legislation and other regulations containing labor law norms, in other words, the state labor Inspectorate checks. The article discusses the main reasons why employees apply for the restoration of violated rights to the state body; also describes in detail the potential risks that the employer bears based on the results of an unscheduled inspection, and finally, employers are given recommendations to minimize the occurrence of conflict situations.

Keywords: employee, employer, conflict, state labor inspection, inspections, risks, complaint.
Божукова Елена Михайловна

Московский гуманитарный университет; начальник отдела кадров, ООО «Белнефтехим-POC», г. Москва elena107@mail.ru

Аннотация: В силу статьи 21 Трудового кодекса РФ одним из основных прав работников является защита своих трудовых прав, свобод и законных интересов всеми незапрещенными законом способами. В нашей статье речь пойдет об одном из способов защиты нарушенных трудовых прав работников - государственном контроле (надзоре) за соблюдением трудового законодательства и иных нормативных актов, содержащих нормы трудового права, проще говоря - проведение проверок государственной инспекцией труда. В статье рассмотрены основные причины, по которым работники обращаются за восстановление нарушенных прав в государственный орган; также подробно описаны потенциальные риски, которые несет работодатель по результатам проведения внеплановой проверки, и, наконец, работодателям даны рекомендации для минимизации возникновения конфликтных ситуаций.

Ключевые слова: работник, работодатель, конфликт, государственная инспекция труда, проверки, риски, жалоба.

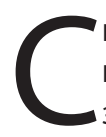
пособы защиты трудовых прав работников, являющимися слабой стороной в трудовых отношениях, закреплены в статье 352 Трудового кодекса РФ. В нашей статье мы не будем подробно останавливаться на каждом из способов защиты, а рассмотрим один из них, на мой взгляд, чаще используемый в практике - государственный контроль (надзор) за соблюдением трудового законодательства и иных нормативных актов, содержащих нормы трудового права, в частности, организация и проведение проверок федеральной инспекцией труда и ее территориальными органами.

В нашей статье мы попытаемся разобраться, почему же работник обращается за защитой своих нарушенных трудовых прав в государственную инспекцию труда. Как уже было упомянуто выше, сторонами трудового договора являются работодатель и работник, но работник является слабой стороной, хотя бы потому, что он находится не наравне с работодателем, а под его управлением и контролем и подчиняется правилам внутреннего трудового распорядка (ст. 15 ТК РФ).

Как показывает практика, в последние годы работники все чаще стали обращаться в инспекцию труда, причем даже из-за малейшего нарушения (по мнению работника) трудовых прав. Во-первых, обращение в ин- спекцию стало крайне доступно - достаточно иметь дома выход в интернет. Во-вторых, работник заранее уверен в том, что никто, кроме представителя государственной инспекции труда, не выслушает его и не накажет работодателя. В-третьих, эффект «сарафанного радио» тоже имеет место быть - «добрые люди» порекомендовали обратиться в государственную инспекцию труда, т.к. они сами ранее обращались, и их нарушенные права были восстановлены.

Что же служит основной причиной обращения работника за восстановлением своих нарушенных прав в государственные органы? Причина проста - неумение и нежелание работодателя ценить свои кадры (человеческий ресурс), что приводит к возникновению конфликта сторон трудовых отношений. Как правило, конфликтующие стороны общаются на эмоциях, иногда даже применяя ненормативную лексику. Конечно же, это недопустимо ни на одном предприятии! Результат такого общения очевиден - конфликт не исчерпан, работник на эмоциях спешит пожаловаться во все инстанции.

Государственная инспекция труда в силу п. 90 Административного регламента, утвержденного приказом Роструда от 13.06.2019 № 160, обязана рассмотреть любое обращение (жалобу) гражданина, за исключением 
анонимного, а также провести внеплановую проверку работодателя.

С какими жалобами чаще всего работники обращаются в государственную инспекцию труда?

- не выплачивается либо выплачивается не в полном объеме заработная плата за полностью отработанное время;

- не оплачиваются листки нетрудоспособности;

- несвоевременная выплата отпускных;

- работодатель заставляет работать сверхурочно без каких-либо компенсаций;

- отказ работодателя в предоставлении ежегодного отпуска;

- при увольнении с работником не произведен окончательный расчет, не выдана трудовая книжка;

- не создаются безопасные условия работы, как это предусмотрено трудовым договором;

- работодатель пытается уволить работницу, находящуюся в отпуске по уходу за ребенком;

- незаконное увольнение либо увольнение с нарушением процедур (как правило, по инициативе работодателя).

Также крайне часто работники обращаются с жалобами на неоформление письменного трудового договора либо на заключение срочного трудового договора без установленных статьей 59 Трудового кодекса РФ оснований.

Работодателю нужно понимать, даже если конфликт будет исчерпан, и стороны найдут выход из сложившейся ситуации, государственная инспекция труда все равно будет обязана провести внеплановую проверку, хотя тот факт, что стороны трудовых отношений самостоятельно достигли перемирия, будет служить смягчающим обстоятельством при вынесении контролирующим органом решения.

Какие же потенциальные риски несет работодатель в случае прихода к нему государственного инспектора труда по жалобе работника?

Во-первых, репутационные риски. Информация о проведенных проверках общедоступна, и любой контрагент, работник, кандидат, имеющий намерения трудоустроиться в данную компанию, могут ознакомиться с результатами проведенных проверок. Работодатель рискует потерять своих контрагентов, кандидатов, особенно уникальных специалистов, на поиск которых ушло много времени и затрат. Что касается коллектива, то авторитет работодателя в глазах работников может «пошатнуться», особенно, если по результатам проверки выявлены нарушения и наложен штраф.

Во-вторых, материальные (денежные) риски. Если го- сударственный инспектор труда по результатам проверки выявит нарушения, то на работодателя будет наложен штраф, размер которого зависит от тяжести нарушения.

В-третьих, административная либо уголовная ответственность.

Наибольшее количество правонарушений государственные инспекторы труда квалифицируют по статьям 5.27 и 5.27.1 Кодекса Российской Федерации об административных правонарушениях.

Следует помнить, что в случае выявления нарушений самым опасным последствием для организации может стать приостановление деятельности организации под предлогом защиты трудовых прав ее работников (ст. 5.27 КоАП РФ) на срок до девяноста суток.

Однако есть нарушения, за которые работодатель несет и уголовную ответственность: задержка и невыплата заработной платы (ст. 145.1 УК РФ); неправомерный отказ в приеме на работу некоторых категорий граждан (ст. 144.1 УК РФ); нарушение требований охраны труда (ст. 143 УК РФ).

По данным Судебного департамента при Верховном суде Российской Федерации только за первое полугодие 2018 года осуждено:

- 64 человека («нарушение правил охраны труда»);

- 1 человек («необоснованный отказ в приеме на работу (увольнение) беременной женщины или женщины, имеющей ребенка до 3 лет»);

- 114 человек («частичная или полная невыплата зарплаты»).

Причем к уголовной ответственности, например, за несоблюдение требований охраны труда привлекается не только генеральный директор, как должностное лицо, их заместители, специалисты службы охраны труда и другие лица, на которых возложена данная функция. А в роли потерпевших могут выступать как работники, так и любые другие субъекты (Постановление Пленума ВС РФ от 29.11.2018 № 41).

В-четвертых, отсутствие информации у работодателя о «зачинщике» внеплановой проверки. Если обиженный работник в своей жалобе в государственную инспекцию труда попросит не сообщать работодателю, кто на него пожаловался, то инспекторы труда в силу статьи 358 Трудового кодекса РФ не вправе сообщить работодателю сведения об обратившемся. Таким образом, даже если работодатель захочет провести разъяснительные действия с «жалобщиком», которые, как правило, приводят к увольнению работника по соглашению сторон или по собственному желанию, это будет крайне затруднительно. 
В заключение хочется отметить следующее: конфликт не возникает из ниоткуда - конфликту всегда предшествует недопонимание, недосказанность, неумение и нежелание слушать и слышать как со стороны работника, так и со стороны работодателя. Любую ситуацию можно решить, не вынося её за пределы организации. Именно так и поступают грамотные работодатели - вступают в конструктивный диалог с работником, независимо от его должности, квалификации, образования, возраста и т.п. и находят решение, которое выгодно для обеих сторон. У такого работодателя отсутствует текучесть кадров, высокая результативность, т.к. работники полностью удовлетворены условиями труда.

Конечно же, бывают ситуации, когда работник злоупотребляет своим правом, не скрывая этого, дабы досадить и работодателю, и коллегам, и клиентам в силу разных причин. В такой ситуации на помощь работодателю может прийти государственная инспекция труда, но это тема уже следующей статьи.

\section{ЛИТЕРАТУРА}

1. Кодекс Российской Федерации 06 административных правонарушениях от 30.12.2001 № 195-Ф3 (ред. от 31.07.2020) // Собрание законодательства РФ. 07.01.2002.

2. Трудовой кодекс Российской Федерации от 30.12.2001 № 197-Ф3 (ред. от 31.07.2020) // Собрание законодательства РФ. - 07.01.2002.

3. Уголовный кодекс Российской Федерации от 13.06.1996 № 63-Ф3 (ред. от 31.07.2020) // Собрание законодательства РФ. - 17.06.1996. - № 25. - ст. 2954.

4. Постановление Пленума Верховного Суда РФ от 29.11.2018 N 41 «0 судебной практике по уголовным делам о нарушениях требований охраны труда, правил безопасности при ведении строительных или иных работ либо требований промышленной безопасности опасных производственных объектов» http://www.consultant.ru/document/cons_doc_LAW_312308/

5. Приказ Роструда от 13.06 .2019 N 160 (ред. от 22.04.2020) «0б утверждении Административного регламента осуществления Федеральной службой по труду и занятости федерального государственного надзора за соблюдением трудового законодательства и иных нормативных правовых актов, содержащих нормы трудового права» (Зарегистрировано в Минюсте России 10.10.2019 N 56195)

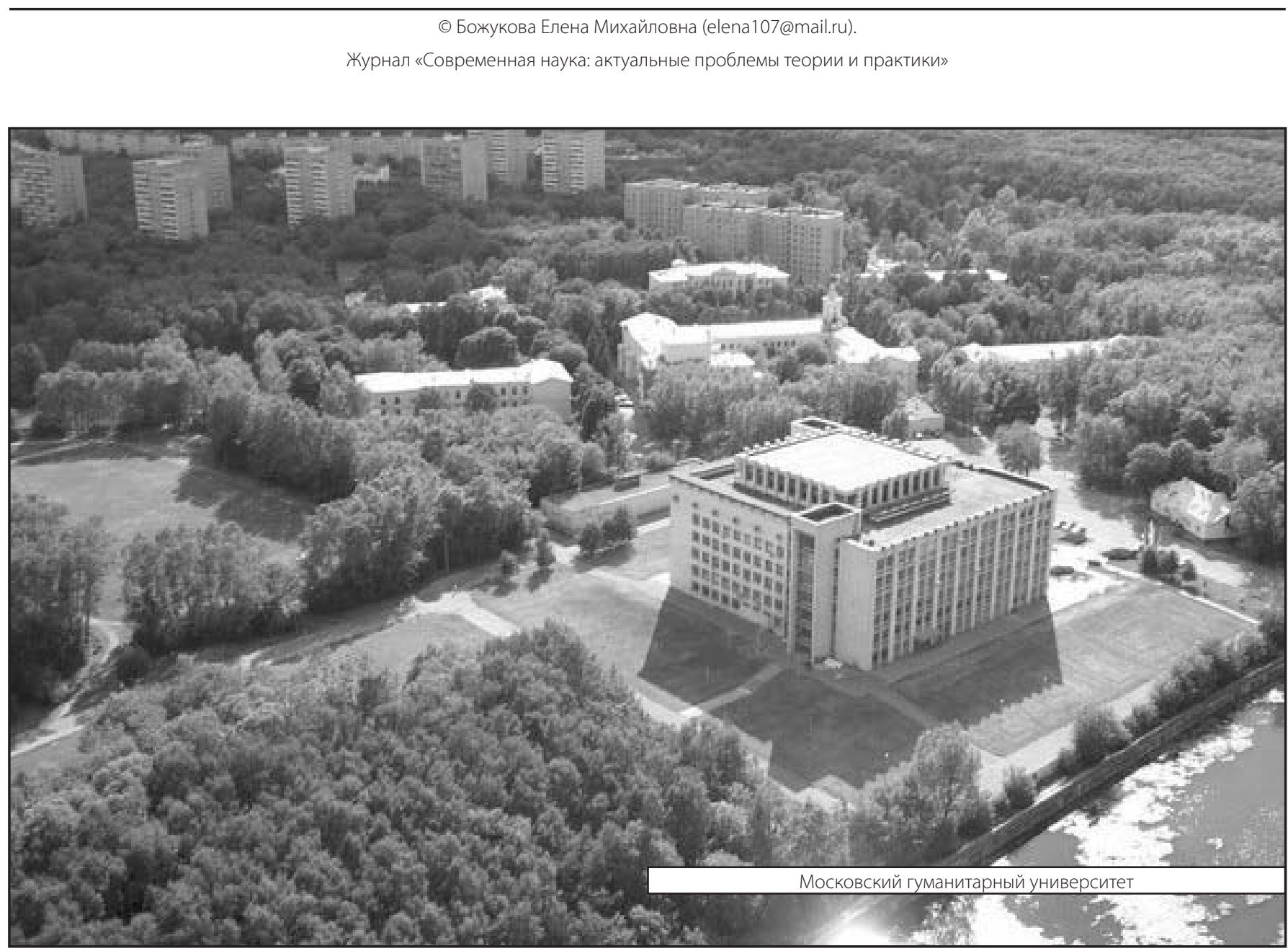

